\title{
THE GOSPEL ACCORDING TO ROBERTO: A THEOLOGICAL POLEMIC
}

\author{
H. JefFerson PowelL*
}

Roberto Mangabeira Unger occupies a prominent, if ambiguous, place in contemporary American legal culture. Along with Duncan Kennedy and Morton Horwitz, Unger is usually regarded as one of the creators of the imtellectual and academic/poitical movement that calls itself Critical Legal Studies. Unger has also played a role in the world of governmental politics: he lielped to found the contemporary democratic leftist movement in his native Brazil. ${ }^{1}$ And unlike most CLS members, Unger in the past has identified his work as Christian in its intellectual underpinnings. ${ }^{2}$

In this Essay, I want to take seriously Unger's theological self-identification as a basis for interpreting his latest (and apparently incomplete) work, Politics: $A$ Work in Constructive Social Theory. ${ }^{3}$ Even in its present form, Politics is Unger's lengthiest work, and his most ambitious intellectual project since Knowledge and Politics. Building on the work that he has done in the interim in legal and social theory ${ }^{4}$ and in the philosophy of personhood, ${ }^{5}$ Unger has now accomplislied a considerable amount of the great task he set for himself in his programmatic essay The Critical Legal Studies Movement: 6 the creation and presentation of a political program einbodying a "visionary insiglit into a reordered social

* Visiting Professor, Duke Law School; Professor of Law, University of Iowa. I deeply appreciate comments and criticisms by Carol Barry, Kate Bartlett, Lawrence Baxter, Stanley Hauerwas, and Denise Thorpe.

1. See Simon, Social Theory and Political Practice: Unger's Brazilian Journalism, $81 \mathrm{Nw}$. U.L. REV. 832 (1987) (discussing Unger's activity as a political journalist in Brazil).

2. R. UNGer, PASSION: AN ESSAY ON PERSONALITY 22-29 (1984); Kronman, Book Review, 61 MiNN. L. REV. 167, 203-04 (1976) (reprinting letter from Unger to Kronman).

3. Unger's Politics (1987-) currently consists of threc volumes:

(1) Social THEORY: ITS SITUATION AND ITS TASK;

(2) FAISE Necessity: ANTI-Necessitarian Social Theory in the SERvice of RadicaI DEMOCRACY; and

(3) Plasticity into Power: Comparative-Historical Studies on the Institutional CONDITIONS OF ECONOMIC AND Military Success.

This Essay will cite the volumes of Politics by the numbers that I have assigned; e.g., 1:44 is a reference to p. 44 of Social Theory.

4. See R. Unger, LAw in Modern Soctety: Toward a Criticism of Social Theory (1976).

5. See R. UNGER, supra note 2.

6. R. Unger, The Critical Legal Studies Movement (1986). 
world."7 Such a program, Unger insisted in that essay, would require a "credible theory of social transformation," "a conception of the ideal that should guide the reconstruction of ... institutional forms,"9 and an account of the regenerate "direct practical or passionate dealings among people" that necessarily would accompany the remaking of the institutional order. ${ }^{10}$ This is no small task, to put it mildly, and in carrying it out Unger has displayed remarkable energy and an admirable willingness to rethink his own previously expressed views.

Nowhere in Politics does Unger directly lay claim to a Christian stance, or adopt in his own voice exphicitly faithful language. ${ }^{11}$ I shall argue nonetheless that Politics is a deeply theological work, and that it may usefully be examined froin a theological viewpoint. Indeed, I shall go further and claim that Unger's work demands such an evaluation: Politics offers its reader a richly detailed and symbol-laden account of liuman existence, an account that possesses cosmic scope and emotional depth; it purposively offers its readers a "symbohic structure through which [their] commumity [might] view reality, truth, and value and thus through which it [might] express its perspective on the world and on itself." 12 One response to such a work is to evaluate it from the standpoint of theology-the discipline that seeks to examine reflectively and critically such symbolic structures. ${ }^{13}$ An analysis of Unger's theology will enable us, I hope, to evaluate his specific political and legal proposals more readily. ${ }^{14}$

This Essay is divided into six sections. In the first I briefly examine Unger's rhetoric in an effort to defend the claim that Politics miplicitly

7. Id. at 19.

8. Id. at 22.

9. Id.

10. Id. at 25 .

11. Compare R. UNGer, KNOwLenge AND Polrtics 295 (1975), in which the author directly addresses God. (1979)

12. L. Gilkey, Message and Existence: AN INTROduction to Christian Theology 55

13. The value of a theological interpretation of a work such as Politics is not limited to those who slrare the interpreter's own theological and philosophical views. Unger's fundamental vision of "reality, truth, and value" is inseparable from his political program: the primary task of the theological interpreter (as opposed to the legal commentator, for example) is to understand what that vision is. For a discussion of the place of theology in modern intellectual discussions, see H.R. NIEBUHR, Theology in the University, in RAdical MonOtheism AND WESTERN CULTURE 93 (1960).

14. In an excliange of letters with Professor Anthony Kronman that was published as an appendix to Kronman's review of Unger's Knowledge and Politics, Unger asserted that Kronman's criticisms stemmed at least in part from a failure to recognize the Clrristian and indeed Catholic background to Unger's work. Kronman, supra note 2, at 200-01. I certainly agree with Unger that his readers need to address his theology, but it is ironic that Unger directed this completely legitimate complaint at Kronman, one of the most philosophically and theologically sophisticated of contemporary legal scholars. 
asserts a prophetic and even scriptural character. The following four sections address what I identify as Unger's accounts of creation, redemption, church, and the state of salvation. ${ }^{15}$ In the conclusion I identify gnosticism ${ }^{16}$ as the appropriate theological categorization of Unger's thought.

A final observation: this Essay is not a complete or a putatively neutral review of Unger's work. A great deal of Politics, especially Unger's social critique of contemporary Western culture, seems to me insightful and, indeed, perfectly consistent with traditional Christian beliefs. Unger is a major contemporary exponent of the Christian tradition's "commitunent to . . social iconoclasm,"17 and in reading Politics theologically, I have sought to address his ideas within an interpretive framework that I share with him. But for all its power and seductiveness, the vision of human existence that underhes Politics is, I believe, profoundly disturbing and profoundly wrong. I therefore have written a polemic against this vision, rather than a complete review of Politics. The reader should bear in mind the partial (in both senses) nature of this Essay.

\section{SCRIPTURE: UNGER AS EVANGELIST}

Near the beginning of the introductory volume of Politics, Unger expresses a refreshing sense of his own limits: "When the larger argument falls into confusion and obscurity, when I stagger and stumble, help me. Refer to the purpose described in this book and revise what I say in the hight of what I want" (1:9). This personal humility is not inatched, however, by Unger's predominant style of rhetoric in Politics. Rather than inviting conversation and correction, Unger's language asserts authority and demands assent. In doing so, Unger has created for those who assent to his program a text that claims authority parallel to that enjoyed by the Bible in traditional Jewish and Christian thought.

The purpose of Politics, we are told, is to lead us to successfully "learn and practice the gospel of plasticity" (3:2). ${ }^{18}$ Unger seeks to launch "a new and more powerful assault upon superstition and despot-

15. Creation, redemption, church, and salvation are, of course, theological concepts that, as I use them, derive their meaning from Christian theology. My application of these concepts to Unger's thought is provisionally justifiable because Unger himself has identified Christianity as a major source of his thought. See, e.g., R. UNGER, supra note 2, at 22-39. A final judgment about the usefulness of these concepts depends on the degree to which they further our understanding of Unger's work, a judgment that the reader must make.

16. For a definition of this term, see infra note 34 and accompanying text.

17. R. UNGER, supra note 2 , at 24.

18. "Plasticity" is Unger's most frequent label for the state of social relationships, free of hierarchy and division, that he wishes to create. See, eg., 1:59, :210-14. 
ism" (1:3) than was mounted either by the emancipatory political movements of the modern West or by "the social iconoclasm of the world religions" (1:57). Unger describes social theories witl which lie disagrees as burdened with "the superstitions of false necessity" (1:172). He labels their acceptance of a naturalness or fixity of social structure as "the sm the prophets called idolatry" (1:18).

In contrast, Unger's own social theory is a sustained attempt to prophetically "disrupt" the link between the status quo and our understanding of "ultimate reahty" (1:43). His affirmative goal is "to lift the burden of rigid hierarchy and division that weighs on our practical and passionate relations with one another" (1:5). ${ }^{19}$ To live out the political and "personalist" program that Unger presents would be both evangelical and redemptive: Unger's express goal is to bring others into a new relationship with themselves and one another that is freed of enslavement to the oppressive forces of the old life. Writing of the atteinpt to inake his vision a reality, Unger states that "[w] $[\mathrm{w}$. [in the program] goes well ... [it] invokes a higlier, renewed order of human life and demands an assent whicl is also a redernptive coinplicity" (2:412). Success for Unger would be the creation of a "regenerate community" (1:39).

Politics is suffused with this type of quasi-rehigious language. I believe this to be neither accident nor mistake. Politics aims to present a world view witl all-embracing descriptive and norinative force, to persuade the reader to accept Unger's message, and by doimg so to enter his movement and denounce other visions as idolatrous and in error. Unger presents us with a gospel and calls on us to accept it.

\section{Creation: The Sovereignty of Imagination}

Christianity has traditionally rejected all accounts of the umverse that deny God's radical creativity. God spoke and creation was. In creating, God neither struggled with dark forces of chaos (as in ancient Near Eastern mythology) nor imposed forin on preexisting inatter (as in mucl1 Greek thought). Ratlier, God is Creator in the strong sense that He made all that exists ex nihilo, out of nothing. Witl regard to divine freedom, therefore, both the particularities and the very existence of creation are wholly contingent: they need not be as they are. ${ }^{20}$

The account of the umverse in Politics retains the doctrine of creation's traditional themes, but gives them a dramatic twist. In the Unger-

19. Cf. Isaiah 9:4 ("the yoke his burden ... Thou hast broken").

20. For a discussion of the Christian doctrine of creation, see L. GILKEY, MAKER OF HEAVEN AND EARTH 13-105 (1959). 
ian universe, the creative actor is humanity individually and collectively, and the agency of creation is the human imaginative will. The world is radically contingent because we can imagine it different. Unger's epistemological starting point is that we can understand soinething only by subjecting it to our imagination, coinparing it to what it is not and making it bend to our transformative powers of fantasy and reconception. "You understand a portion of reality by passing it, im fact or fantasy, through transformative variations: by imagining it other than what it is or seeins to be" (1:30). To understand "any part of reality" is to imagine "it transformed" (1:43). Knowledge is thus an active function of human assertion, of imposing the mind's choices on the things to be understood. This is equally true of all forms of human thought and inquiry. Social and political debate rests on people's "capacity to invent and to judge social ideals" (1:39). Law ultimately rests on the imaginative creation of "ideals of human association" (2:452; see also $2: 513)$. In the writing of history, "authenticity" is the result of "fidelity to the quality of lived historical experience"-experience that is on Unger's account created by the innagination, rather than by the "naive historiography" of "detail" (2:176). Mathematics, logic, and physics, which even to a post-Kuhurian can seem to be a product at least in part of external or analytic truth, derive their power from their reflection of "soinething fundanental about the workings of the imagination." They are not "a revelation of the way things are and have to be in the world" (1:176). Most fundamentally for Unger, we constitute ourselves and the worlds we live in by our willed acts of inagination. "Through such efforts, and through thein alone, you discover and make yourself" (1:30; cf. 2:251). Indeed, our ideas about the social universe are "self-fulfilling" (2:251).

The willed and inaginative character of the universe lias particular importance in Unger's social theory: such a theory inherently addresses low we should construe the world as a normative matter. Such a vision of the universe means that the social, economic, and political orders within which we live are an "artifact" (1:1) and that society is not "beyond the reacll of the will" (2:401). Something we have made is something we can remake or destroy, and by the same means we employed in creation: "force and imagination" (3:20).

To understand and fully exercise humanity's iniaginative sovereignty over society, we inust employ what Unger regards as the crucial intellectual dichotomy of Politics, "the contrast between frameworks and routines" (1:4). Routines are the ordinary activities, roles, and relationships of social life-what most of us spend most of our time doing. Frameworks (or "structures," "contexts," or "formative contexts," see 1:3) are the underlying elements of society within which and by which we 
carry out and understand routines. "A formative context may consist in imaginative assumptions about the possible and desirable forms of human association as well as in institutional arrangements or noninstitutionalized social practices" (1:89). Contexts shape and condition routines, as well as our persistent conflicts over the "inastery and use" of society's resources (1:3). They are "[t]he imaginative scheme of models of possible and desirable association" in a given society (2:271), and they render communication possible by supplying "a subtext of shared assumptions" (1:151). Formative contexts have two primary characteristics. They change very slowly most of the time, and when they do change significantly through some revolutionary upheaval, the result is a change in "the form and outcome of conflicts" $(1: 152 ;$ cf. $1: 62)$. The inertial weight of contexts and the impossibility of having none at all easily delude people into regarding particular contexts as a given, a natural order of the universe. This "naturahistic premise" (1:23) is at the heart of traditional social and political ideology and contemporary positivist social science. It is only partially and therefore unsuccessfully transcended in modern radical political theories (1:25). It is also dead wrong. There are no givens (other than the inescapability of having some contexts) and there is no natural order. To accord our particular contexts naturalistic status is the primeval sin in Unger's universe. "When we think and act in this way, we commit the sin the prophets called idolatry. As a basis for self-understanding, it is worse than a sin. It is a mistake" (1:18). We create contingent and intangible ideas of interest, identity, and possibility (see, e.g., 1:84-87) in order to contain particular conflicts and thereby stabilize a particular social order (1:151), and then we find ourselves captives or even pious devotees of our own creations. One of the central purposes of Politics is Unger's prophetic call to reject behief in the false necessity of the frameworks in which we live.

Our intellectual and social worlds, then, are the products of our imagination, but they do not contain it. Indeed, no conceivable set of contexts-not even those Unger would have us create-can encompass the power of human will and imagination: "the power of insight outreaches all the statable contexts of thought" (1:20). All forms of traditional thought and activity can be reiinagined to be other than what they are $(1: 32 ; 2: 39)$. It is the primitive superstition of "structure fetishism" to believe that our contexts "iinpose on our practical, passionate, and cognitive relations a script we cannot easily rewrite" (1:201, emphasis added).

Politics presents a bold reworking of the Christian doctrine of creation. The God who created lieaven and earth out of nothing by the Word has been replaced by the humanity that creates its world by the force of its individual and collective imagination. Just as the Christian God was 
under no external constraints other than those of logic, so Ungerian men and women finally are limited only by the formal requirement that they must have some contexts. What contexts they choose is essentially a matter of their "insight and fecundity" (1:216). It is perhaps not entirely msignificant that Unger likes to use the word "script" for the (false and idolatrous) notion that there are contexts external to human imagining: in the Ungerian universe we are free to rewrite whatever lines we seem to have been given because we are the playwrights.

\section{Redemption: The Primacy of Self-Assertion}

Traditional Christianity teaches that human beings are created good but that something is nevertheless wrong. The diagnosis of what is wrong eniploys images and concepts such as those of the Fall and of sin. The "cure" is the Christian doctrime of Redemption. ${ }^{21}$ The men and women of Unger's universe hive in a world that they have created, but they too are strangely alienated. The very contexts that they create to enable them to contam violence and make communication and community possible have become oppressive, confining, threatening. The contexts exercise "a shaping, incantatory, even redentptive influence [Unger clearly means falsely redemptive; see the passage] upon the dark, labile force of [human] emotions" (1:24).22 The works of our imaginations take on a life of their own and offer a false security in return for our idolatrous acceptance of their naturalness. Unger offers the doctrines of formative context and false necessity as the diagnosis of our alienation.

Into this grim world, in which the very longings of our hearts are limited and mocked (2:584), Unger sends the good news of a way to re-

21. On the Christian concepts of sin and the Fall, see Sponheim, Sin and Evil, in 1 CHRISTIAN Dogmatics 359, 363-431 (C. Braaten \& R. Jenson eds. 1984). In traditional Christianity, the state of alienation and sin in which human beings find themselves cannot be overcome by human action, but only through God's gift of the "freedom to accept [God's] own forgiving and redeeming selfcommunication." K. RAHNER \& H. VORGRIMLER, DictionARY OF THEOLOGY 433 (2d ed. 1981). "The idea of self-redemption fails to do justice to the true nature and absolute depth of our need of redemption (efforts towards emancipation and the realization of justice are necessary manifestations of redemption, but are not its essence)." Id. For Unger, in contrast, we are the only and sufficient agents of our liberation.

22. The context is Unger's discussion of the reasons why the "naturalistic premise," and the given or "canonical" social orders that it underwrites, exercise so powerful a sway over human thought and action despite the premise's falsity (1:24):

Finaliy, the canonical form of social life is natural because it is seen as connecting fundamental truth about society to equally basic truth about personality. The import of this correspondence must be left deliberately loose: it bears different philosophical interpretations. All clear-cut versions of the naturalistic premise, however, attribute to the personality some proper order of emotions, or of virtues and vices. This order sustains, and is in turn renewed by, the arrangements of the larger society. A person's repeated willingness to meet the claims that the natural social order assigns to him exercises a shaping, incantatory, even redemptive influence upon the dark, labile force of his emotions. 
demption. To be freed, he teaches, we need only assert our wills. Politics, to be sure, reads more like an academic exercise than a proselytizing sermon, but to Unger this is an illusory distinction. The struggle for redemption "may be pursued in imaginative work rather than out in the open" (1:29). Politics, therefore, is a highly theoretical work ("unabashed theorizing" (2:8)) that is nonetheless directly redeinptive in its goals. "A fully developed social theory interprets our efforts at individual and collective self-assertion" (1:15) and precisely by doing so makes redemptive, successful self-assertion possible.

Unger's account of the redeinptive act of assertion is built, he insists, on the elements of the older "radical commitment" to emancipation (see 1:1-17). That commitinent had two clearly related aspects: "the subversion of social division and hierarchy and the assertion of will over custoin and coinpulsion" (1:6). These aspects are, given Unger's understanding of the innagined character of the world, opposite sides of the coin of "conscious mastery" (2:279) over all elements of our individual and corporate lives. We are redeenned from captivity to the structures our imaginations create when we assert intentional control over thein (becoming "fully the masters of our contexts" (2:99)). The progress of our emancipation can be precisely ineasured by "our success at gaining inastery" (2:291).

Unger's faith in redeinption through self-assertion directly informs his political program. The goal of leftist politics, he claims, is the establishment of a "radical" or "einpowered" democracy in which the traditional democratic themes of popular sovereignty and electoral decisionmaking are carried out in a consistent and thoroughgoing inanner. The result will be a polity "that carries to [an] extreme the authority of coinbinations of will over social arrangeinents" (2:213). Einpowered democracy, in short, is the collective form of the assertion of the unbridled will.

We may live out redeinptive self-assertion specifically through the act of context-smashing, or, in another of Unger's peculiar phrases, "negative capability" (2:393). ${ }^{23}$ Because our capacities of will and imagination transcend any of the contexts that we create with them, we can violate the linits we have set. We can destroy by the same means that we use to create. In so doing we directly experience freedoin: "We think and act, at such moinents, as if we were not ultimately limited by anything" (1:18).

23. The expression itself is sometimes used by literary critics, but with a different meaning. See, e.g., E.D. HIRSCH, VALIDITY IN INTERPRETATION ix (1967) (A "compelling writer reminds us that wisdom lies in 'negative capability'-the capacity to be 'in uncertainties, mysteries, doubts, without any irritable reaching after fact and reason." "). 
Described at its most general, context-smashing sounds like an impossibly heroic venture. Fortunately, Unger tells us, it actually builds on something goimg on all the time in society. Social order is actually constituted in part by ongoing minor conflicts over power. These conflicts are usually understood to be taking place within existing frameworks and thereby to be reaffirming them. But such "context-preserving" conflicts can escalate. The development of negative capability entails diminishing the distance between such clashes and "context-transforming conflict" that shatters, rather than preserves, the structures (1:7-8). Individuals who recognize "the primacy of transforming demal" (1:30), i.e., the selfassertive refusal to accept the hinits of our contexts, can shatter the established order of our confining cominumities (1:59). In doing so, they realize their own ennancipation and further the cause of general freedom. In fact, Unger argues, our quest for fulfillment proceeds mainly through acts of context-smashing. "Our practical, theoretical, and spiritual progress is largely the record of these repeated limit breakings" (1:18).

Unger appropriately personalizes the redemptive activity of self-assertion in his notion of the "transformative vocation." The idea is that, as Unger's modernist account of personality reveals, ${ }^{24}$ the only means of defining a free self as against formative contexts is to hive a life characterized by transgression of the limits. "To be fully a person ... you must engage in a struggle against the defects or the limits of existing society or available knowledge" (1:29). The transformative vocation is to treat even the most mundane "routine dealings" of life as "possible objects of a transformative will and imagination" (3:11). For Unger, a redeemed life is one that faces and exults in our "ineradicable homelessness in the world" 25 by continually destroying all our imagniative attempts to build a home here.

In many respects, the heart of Unger's thought lies in this, in the vision of a free-because-transforming mode of life. Indeed, Unger explicitly suggests that Politics can be read "as an attempt to carry to the hilt the view of society and personality within which the idea of the transformative vocation makes sense" (1:35). Emancipation is self-assertion, and self-assertion is the exercise of our capacity to destroy and rebuild our self-created contexts (2:393). Unger acknowledges the existence of a transcendent quality (1:23, referring to our "strange freedom from any given finite structure") to transformative life, but unlike traditional Christians he ascribes it to the individual's prior "residual sense" of herself or himself as the willful, imaginative center of a personal umiverse

24. See R. UNGER, supra note 2 .

25. Id. at 24 . 
(2:320; see also 1:33). The traditional account of redemption as the free gift of the divine Other has been turned upside down into a summons to assert the sovereignty of the self.

\section{Church: The Community of CONFlict}

Unger identifies the chief obstacle to self-assertion as the constraints imposed by formative contexts. Although, as discussed above, the existence of some contexts is necessary or at least unavoidable, whatever contexts in fact arise follow a predictable course by which they stifle the very creativity and willfulness that brought them into being. Formative contexts are generated out of conflict over the basic terms of human society. At some point in every such conflict throughout history, the longing for security has become greater than the desire for change or victory. "Defeated or exhausted, people stop fighting" (1:151). The terms of the ensuing social truce reflect the particular contours of the conflict rather than any foreordained pattern: "The stabilization of a social world requires the spiritualization of violence" (2:398). Nevertheless, these terms gradually assume an appearance of inevitability that enables them to stabilize the social world; they become formative contexts. Contexts differ withm and across societies in the extent to which they are "entrenched" or impervious to challenge and question. The more entrenched a set of contexts becomes, the more rigid and hierarchical the society, and the more difficult redemptive self-assertion becomes (1:154). The inost basic social task for Unger, therefore, is to find a collective way to break the pattern by which contexts become a deadening "frozen politics" of "conflicts interrupted or contained" (1:145).

The answer is "disentrenchment," the process of rendering social structures ever more questionable in all their aspects (1:154-56). Historically this has occurred only in monents of great social crisis that are in the end so exhausting that they lead to a new cycle of hardening social relationships. Disentrenchment must be decoupled from this pattern by becoming a feature of even the most basic assumptions shared during "civic peace" (2:279). The extraordinary must become the commonplace: "a style of factional rivalry [as opposed to civil war] that regularly questions the practical and imaginative foundations to the established social order" (2:465).

The communal form of Unger's gospel is the formation of a community of conflict, a society in which social cohesion is supplied by the very conflict that historic social patterns have attempted to contain or ehminate. All relationships, institutions, and beliefs must have an "indefinite susceptibility to penetration and revision" (3:12). Everything must be up for grabs; the only agenda must be that there is no set agenda; the social 
structure must be an anti-structure, designed to undermine itself continually. The historic pattern by which formative contexts give increasing definition to human nature and to social relationships must be inverted so that even in the most ordinary activities people will recognize "the indefinition of self and society" (2:398). Unger's "ideal" is "a society broken open to everyone's will" ( $2: 404)$.

As Unger intends, the community he describes is one oriented toward self-assertion. It is also-or, rather, therefore-the setting of continual conflict. Unger fully recognizes this fact, and indeed regards it as one of the most important and attractive aspects of his social program. Self-assertive freedom in any group larger than one leads directly toindeed, is constituted by- "contests of force and imagination" (3:20). Like war (see 3:113), conflict is unavoidable; "[t]here must be a victory and a defeat" (2:254). Rather than attempting to deny or escape this reahty, Unger's social theory extols it as the product of freedom in action. Unger ridicules as "an mveterate goody-goody" the would-be radical who does not grasp "the controversial and conflictual character of social life" (2:418). He is equally harsh in his rejection of atteinpts to inagine commumities constituted by peace or reconciliation. Such ideas, he says, rest on a mistaken behef in the possibihty of genuinely "shared values or conflict-free harmony" ( $1: 44 ; c f .1: 70$ on the essentially fictive nature of all shared "interests"). The social vision that results is "[a]n impoverished and unbelievable idea of commuinty" (2:560).

The state is of crucial importance in Unger's account of an eniancipated society. It will be neither transcended in the Kingdom nor discarded after the arrival of the classless society, but will become even more crucial to social life. ${ }^{26}$ Only "central state authority, that great and perilous lever of transformation" ( $2: 432)$, is powerful enough to counteract and break up the tendency of formative contexts to become entrenched, and it must be continuously available for that purpose. One of the most innovative of Unger's specific pohitical proposals, the idea of "destabilization rights," is an atteinpt to envision a legal system in which anyone can invoke state power to challenge any element of social, econonic, or political life in the interest of preventing entrenchment (2:53035). ${ }^{27}$ The state is the crucial collective aspect of redemption because only it can provide "the occasions and the means to challenge and revise every aspect of the basic institutional structure of society" (2:449). Just as the individual is most centrally characterized by her capacity for the

26. Unger strongly dislikes most liberal political devices designed to restrain the state's jurisdiction or power. But see 2:524-30 (Unger's argument for "immunity rights" that would protect physical safety, liberty, and a minimum level of welfare entitlements from interference).

27. See also R. UNGER, supra note 6, at 52-56. 
transformative vocation (see 1:29), so the very "statishness" of the state lies in its "capacity for transformative action" $(3: 80-81,: 85)$.

Unger's message of redemption shares with traditional Christianity the belief that the locus of salvation is in community. ${ }^{28}$ However, Unger's community, his "church," is a curious photographic negative of the Christian vision of the Church as a community of reconciliation and peace. The outward and institutionalized form of Unger's community is a state armed with the power to intervene in (almost) all aspects of human life. Its authority is coercive, and oriented toward exacerbating rather than reconciling conflict. Its central and characterizing activity is the tearing down of existing relationships, not their loving reconstitution.

\section{Salvation: The Emancipation of EXPERIENCE}

What then is Unger's ultimate vision, the salvation to which he would lead people? Politics is a long and complicated work, and a great deal of it is concerned with quite detailed discussions of particular socioeconomic and political issues ranging from Unger's notion of a "rotating capital fund" intended to decentralize and deinocratize the economy (2:491-502) to the orgamizational prerequisites for military victory (3:153-206). But throughout all the detail, I beheve, Unger is remarkably consistent in his portrayal of the redeemed life of freedom. Unger sees salvation as the emancipation of humans from anything and everything that limits their capacity for experience and for the exercise of imagination and will.29

Unger expresses this goal in a number of ways. At the beginning of Politics, Unger describes the work's purpose as the total development of "the liberal and leftist aim of cleansing from our forms of practical collaboration or passionate attachment the tamt of dependence and domination" (1:1). Salvation as freedoin from dependence and domination is a pervasive theme in Politics. At one point Unger refers to "the dangers of dependence and depersonalization" (1:155). Indeed, dependence, domination, and depersonalization are ahnost synonyinous for Unger. If selfassertion is the redemptive mode of establishing one's personhood, dependence on another amounts to domination by her. Dependence is depersonalization. (Unger's rejection of dependence extends to ideas that

28. On the centrality of community to Christian thought and action, see S. HaUERWAS, A COMMUNity OF CHARACTER (1981).

29. Traditional Christianity understands salvation as the accomplishment of God's purposes in creating humanity, including "the fulfillment of what is natural" in human existence, "the reestablishment or restoration of community, and especially of loving community out of estrangement, separation, and conflict," and "the centering of life around the divine center." L. GILKEY, supra note 12 , at 227 . 
human behavior should be constramed by external roles or narratives (1:26-30), since all such ideas "behttle and enslave" the individual (2:23132).)

Unger notes that it is when we break the "practical, theoretical[, or] spiritual" limits to our world that we experience freedom as he understands it - thought and action then proceed "as if we were not ultimately limited by anything" (1:18). In Unger's brave new world, the experience of limitlessness will be extended to "our ordinary social experience" (2:449). Pohitical and social ideas are subject to "the test of personal experience" (2:431) for their capacity to further the goal of placing "the fewest possible constraints upon experimentation" (2:514). Collaborative and relational activities must subserve the development of our "individual life projects" (2:291). In the Ungerian social world, we will be free to "take our cues from wherever we like" in working out our unique selfidentities (2:232). The "ideal effect" of Unger's program on human personahity will be "the enlargement of the imagination" and "the accentuation of desire"-all desire (2:579-80). "This goal holds for desire in general, whatever its specific aim or relative weight" (2:579).

Does Unger really believe in this refurbished version of earlier visions of humanity as the Promethean ego, experiencing all and being touched by nothing and no one? I suggest that he does. At one point Unger candidly remarks thiat the results of his goal of enipowering people to expand their experiences would "differ less than might appear" fron the aimless hedonisn of "the educated middle classes of the rich Nortli Atlantic countries" (2:544). Even more chillingly, in an earlier draft of Politics, Unger explicitly stated that his goal was to impart to all of social life "what the Marquis de Sade recommended for sex: the strenuous enlargeinent of enacted possibility." 30 Unger lias toned down the rlietoric of that particular passage in the published version, but the message remains the same. Ungerian salvation is the realized possibility of exploring all conceivable experience, heedless of any limits and in the service of individual greatness $(2: 579,584)$.

What sort of people would-or could-live in the world of Ungerian emancipation? Unger rejects the notion that they would possess some intrinsically healthy range of emotions or a character formed by the exercise of particnlar virtues: there is no "proper order of emotions, or of virtues and vices" (1:24). Nor would emancipation restore hunianity to some sort of pre-enslavement purity: when innocence rather than imagination and capacity is made someone's goal, achievement of that goal "corrupts" her (2:115). Unger recognizes that only a Nietzcliean Over-

30. Ball, The City of Unger, 81 Nw. U.L. REv. 625, 655 n.159 (1987). 
man could relish living in his community of conflict. "People who can readily put on their agenda the foundations of the world they inhabit must be haughty, high-spirited, and even reckless. They must be secure in an inviolable independence" (2:134). When such persons appear in history (such as Napoleon; see 2:581-85) or hiterature (such as Bazarov in Turgenev's Fathers and Sons ${ }^{31}$ ), they either fascinate or repulse more ordinary folk; they always seein different or strange to the rest of us. Just so: human freedoin according to Unger is a "strange freedom" (1:23) and its achieveinent by the "ordinary person" would make her "more like the poet, whose visionary heightening of expressed emotion may border on unintelligibility and aphasia" (2:566).

It is only by ruthlessly smashing our stabilizing and confining contexts that we can find "happiness and ennoblement" (2:304) and satisfy our "hidden and insulted longing for greatness" (2:584). Unger responds explicitly to the anticipated charge that this vision is "almost enipty" of substantive content in that it "do[es] not tell us what" the particular forms of our individual and collective greatness will be (2:580). He rejects the charge on two grounds. First, his social theory yields a concrete institutional progran, and second, it is not possible even in theory to develop a "canonical list" of desirable outcomes (2:580). It is intrinsic to Ungerian freedon that the results of its exercise will be strange and surprising. (The thenes of strangeness and surprise are pervasive in Politics. See, e.g., 1:5, 1:34, 1:127, 1:146, 2:110, 2:213, 2:218.) More fundamental yet is the fact that for Unger, redemptive self-assertion is nuaster, not servant, of the goals it selects: "Ineans create their own ends" (3:13). For the emancipated person, the clear distinction that the rest of us see between a "social order cleansed of force and fraud" and one dominated by "treachery and violence" fades from view (1:45). For her, the choice is not between good and evil, but between choice itself and enslavenient.

Unger's vision of salvation is, fron 1 a traditional Chrisuan perspective, a nightmare. His social goal is to create a world without community or tradition, to write an anti-narrative in which all we share is struggle and mutual surprise. In the New Testament we are told that faith, hope, and love will abide; in the Ungerian world, these, like all other virtues, dispositions, and behefs, nuust be sacrificed so that "fuller forms of self-assertion and attachment" can emerge (see the entire, extraordinary passage, 2:575).

31. In an unpublished paper I have explored Turgenev's portrayal in Fathers and Sons of how an "emancipated" personality would appear. See J. Powell, Images of the Nihilist in Turgenev's Fathers and Sons (Jan. 15, 1988) (unpublished manuscript; copy on file in offices of Duke Law Journal). 


\section{CONCLUSION}

This Essay began with the interpretive decision to approach Politics from a position shaped by Unger's explicit and implicit theological claims. Such an interpretive stance, I have suggested, takes Unger's genuine roots in the Christian theological tradition seriously. The value of this approach, at least in part, has been to highlight the remarkable parallels and enormous dissimilarities between Unger's thought and traditional Cliristianity. Politics presents an account of creation (through human imagination), redemption (through self-assertion), church (the "community" of conflict), and salvation (the limitless expansion of the range of experience). The attractiveness of his detailed political program ouglit to be evaluated in the context of this vision. The program, after all, is a serious attempt to outhine the means for transforming our social world of false necessity into Unger's emancipated umiverse of "haughty, high-spirited, and even reckless" individualists (2:134). The program's success would create a world in which even our profoundest accomplishments in personal relationships and social justice would be subject to radical overthrow and rejection-Unger cannot and does not limit the scope of negative capability to the destruction of morally objectionable elements in our contexts. All of our contexts-our beliefs, practices, institutions, and relationships-can and in the end must be sacrificed on the altar of empowerment (see 2:575). Those for whom this vision is not morally attractive ought to hesitate to accept a program intended to implement it.

Professor Unger's fundamental vision resembles that of the nineteenth and twentieth century "modernists" whom he admires (1:22223). ${ }^{32}$ But Politics has parallels in a much earlier period. Unger's radical gospel of emancipation looks very inuch like a brilliant repristination of that ancient Christian heresy, ${ }^{33}$ gnosticism. ${ }^{34}$ Near the beginning of Politics, Unger refers to what he calls "one of the oldest and most puzzling themes of our civilization: the idea tliat man is the infinite caught witlin the finite" (1:17). Many of the ancient gnostics saw hunian beings-at least those with "pneumatic" (spiritual) natures-as alien visitors from a

32. See also R. UNGER, supra note 2, at 7-39 (discussing in detail the inodernist thesis about contexts).

33. My comparison of Unger's vision to an ancient heresy is deliberate. Theologically, a heresy is a grave error of thought and commitment made by someone within the theological cominunity: "The heretic takes a truth out of the organic whole which is the faith and ... misunderstands it," $\mathrm{K}$. RAHNER \& H. VORGRIMLER, supra note 21, at 206.

34. Ancient gnosticism was a theological movement or collection of movements that stressed the power of individuals-or at least of the spiritual elite - to free themselves from alienation by acquiring knowledge (im Greek, gnosis) of their true identity. See J. Kelly, Early Christian DOCTRINES 22-28 (rev. ed. 1978). 
heavenly realm, trapped by matter and ignorance in a world to which they were by nature superior. Redemption was available through the attainment and exercise of the true gnosis (knowledge) about the pneumatics' origins and predicament. The gnostic's vocation thus was not to contribute to the building up of a community of reconciled sinners constituted by a particular history, but to free herself from all earthly limits. Unger's new gnosticism revives this ancient myth, and reproduces many of the conceptual and ethical problems that contributed to mainstream Christianity's rejection of gnosticism: its excessive optimism in the poiver of the mind, its disdain for the particularized and material embodiment of human existence, its ethical ehtism. His gospel is that "the gates of universal spiritual seduction" (1:57) are open, and that passimg through them we can achieve mastery and experience freedom "from any given finite structure" (1:23). We are capable of infinity, Unger promises, if only we dare to reach out and mold our own destinies. Thus spake the serpent to Eve. 